\title{
Phase-Shift, Targeted Nanoparticles for Ultrasound Molecular Imaging by Low Intensity Focused Ultrasound Irradiation [Corrigendum]
}

Li M, Luo $\mathrm{H}$, Zhang $\mathrm{W}$, et al. Int $J$ Nanomedicine. 2018;13:3907-3920.

The authors have advised that they covered up some larger-sized particles and impurities to enhance the aesthetic of the image shown for Figure 4A, on page 3913. The authors also removed some impurities and enhanced certain aspects of the image shown for Figure 4B.
These two images were used to display the general appearance and shapes of the nanoparticles the authors had successfully prepared in the study. The editor determined that while the images had been altered it did not affect the conclusions of the study.

The authors wish to apologise for these errors. The correct Figure 4 is shown below.
A

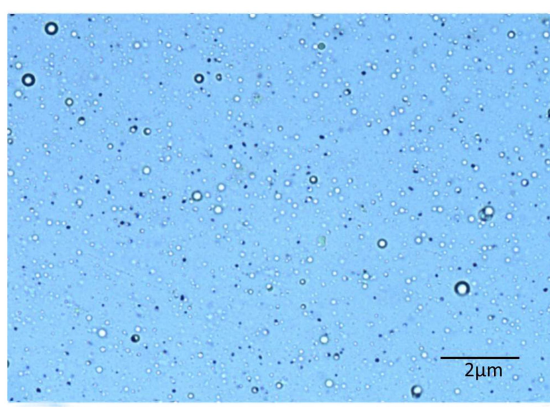

D

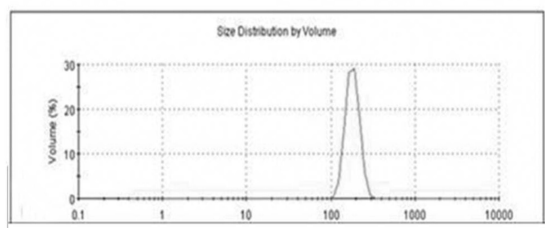

Size distribution of PFP/PLGA-PEG-FA nanoparticle

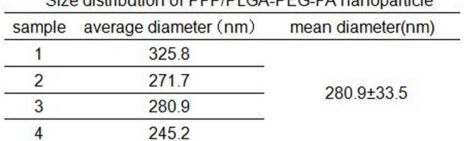

B

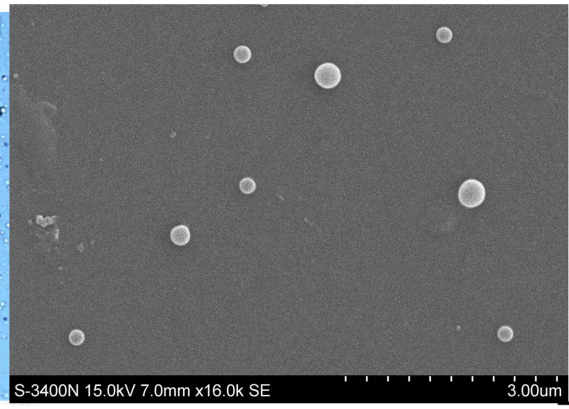

E
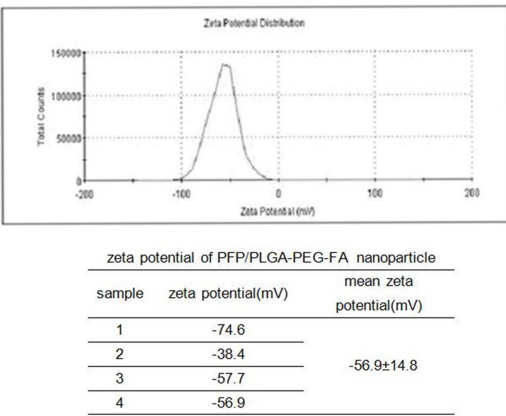

C

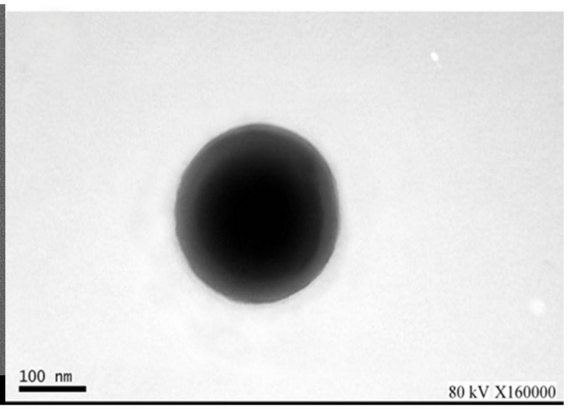

$\mathbf{F}$

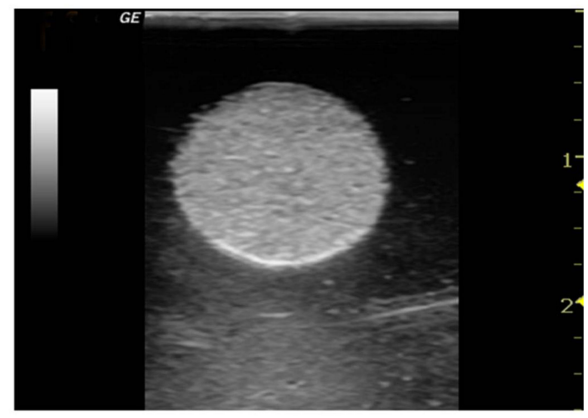

Figure 4 PFP/PLGA -PEG -FA nanoparticle characterizations.

Notes: (A) Bright field optical microscopy. (B and C) SEM and TEM image of the nanoparticles. (D and E) Size distribution and zeta potential of the nanoparticles. (F) In vitro US image of the nanoparticles.

Abbreviations: FA, folic acid; PEG, polyethylene glycol; PFP, perflenapent; PLGA, poly lactic-co-glycolic acid; SEM, scanning electron microscopy; TEM, transmission electron microscopy; US, ultrasound.

\section{Publish your work in this journal}

The International Journal of Nanomedicine is an international, peerreviewed journal focusing on the application of nanotechnology in diagnostics, therapeutics, and drug delivery systems throughout the biomedical field. This journal is indexed on PubMed Central, MedLine, CAS, SciSearch ${ }^{\circledR}$, Current Contents ${ }^{\mathbb{R}} /$ Clinical Medicine, $^{-}$
Journal Citation Reports/Science Edition, EMBase, Scopus and the Elsevier Bibliographic databases. The manuscript management system is completely online and includes a very quick and fair peer-review system, which is all easy to use. Visit http://www.dovepress.com/ testimonials.php to read real quotes from published authors.

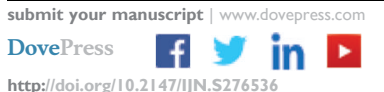

http://doi.org/10.2147/IIN.S276536 